\title{
Assessment cultivated period and farm yard manure addition on some soil properties, nutrient content and wheat yield under sprinkler irrigation system
}

\author{
Ebtisam Eldardiry ${ }^{1^{*}}$, Farid Hellal ${ }^{2}$, Hani Mansour ${ }^{1}$, Mohamed Abd El Hady ${ }^{1}$ \\ ${ }^{1}$ Water Relations and Field Irrigation Department, National Research Centre, Giza, Egypt; \\ *Corresponding Author: ebtisameldardiry@gmail.com \\ ${ }^{2}$ Plant Nutrition Department, National Research Centre, Giza, Egypt
}

Received 5 December 2012; revised 8 January 2013; accepted 16 January 2013

\section{ABSTRACT}

This study examined changes in some soil hydrophysical, chemical properties and wheat yield (grain; straw yield, N, P, K, Protein and carbohydrates contents) as trends under two cultivated period 10 and 25 year and Farm Yard manure (FYM) addition under sprinkler irrigation system on a newly reclaimed soils, Nubaria, Beheira Governorate, Egypt. Obtained results noticed that cultivation period has more pronounced effect than FYM addition on soil water content at field capacity, wilting point and available water with increase percent $15.1 \%$, 9.3\%; $19.0 \%$ and $25.7 \%, 19.5 \%$ and $30.0 \%$ for FYM and cultivation period comparing with control one. Hydraulic conductivity values were strongly affected by cultivation period and FYM addition and significantly decreased values by about $18.9 \%$ and $12.1 \%$ in same sequences. Wheat straw content from protein had a superior effect under 25 than 10 years cultivated periods with values 61.9 and 6.7 comparing with control, respectively as affected by FYM addition, while FYM alone improved protein content in straw by about $31.9 \%$ comparing with untreated one. Slightly increase in straw protein content was attained relative to the increase of cultivated period by about $7.8 \%$. Nutrients content in grain is more than FYM, where the increase percentage were $5.2 \%, 13.5 \% ; 3.8 \%$ and $26.5,21.3 ; 22.6$ comparing cultivated periods 25 with 10 years and FYM addition with control, respectively. FYM individually under two studied cultivated periods is more effective under 10 years $(28.0 \%$, $25.2 \% ; 15.1 \%)$ than the 2 nd one $(25.1 \%, 25.2 \%$; 15.1\%) comparing with untreated FYM plots. While $N, P$ and $K$ content in wheat straw had unclear trend and the increase were 6.8, 23.23; $56.5 \%$ and $62.9,6.0 ; 29.8$ as a result of FYM addition under 10 and 25 years cultivated periods, respectively. The highest values of protein and carbohydrates content in wheat grains as affected by studied factors were $12.86 \%$ and $67.43 \%$ ) were obtained under cultivated period 25 years after FYM addition. Cultivated periods had a highly significant effect on the field water use efficiency values of grain more than the effect of FYM. The highest values of grain and straw yield were recorded at 10 years cultivated periods + treated FYM $(2966.8 \mathrm{~kg} / \mathrm{fed})$ and 25 years cultivated periods treated with FYM (3835.6 kg/fed). Cultivated periods increased grain and straw yield of wheat crop by about $57.6 \%$ and $\mathbf{8 . 3} \%$. Whereas, FYM increased grain and straw yield by about $39.8 \%$ and $\mathbf{5 8 . 8 \%}$ relative to the control, respectively.

Keywords: Sandy Soil; Hydrophysical; Chemical Properties; Farm Yard Manure; Nutrient Content; Irrigation; Wheat Yield; Sprinkler

\section{INTRODUCTION}

It has been predicted that human cereal demand will increase as a result of population increase. Hence, sustainable increases in crop yields are needed to ensure food security in Egypt. Consequently, the judicious and scientific management of soil and water resources is essential to meet the demands for cereals. Soil management practices have profound impacts on soil fertility, which is closely linked to land productivity. As soil processes are often slow, it is only through long term management that they can improve soil characteristics to enhance crop production. Necessitating increases in the mean grain yield of these cereals; the need will be especially great in 
the developing countries [1]. Wheat is considered one of the most important and strategically cereal crop in Egypt, but its cultivated area produced only about $30 \%$ of the domestic needs. There are several ways for increasing wheat production; one of them is the appropriate application of organic matters, especially in the newly reclaimed areas [2].

Organic matter is a key component of the soil because it carries out many functions in agro-ecosystem and it is applied to the soil to improve their physical, chemical and biological properties [3]. Fliessbach et al. (2000) suggested that, Farm yard manure (FYM) application increased the transfer elements between the solid phase and soil solution in addition to higher microbial activity. They also, reported that organic soil management improved the soil structure by increasing soil aggregate, thus reducing the risk of soil erosion and promoted the development of the earth condition for plant. The activity of soil microorganisms was higher in the organic farming system, which helped the nutrient uptake to be faster [4]. Dalal and Mayer (1986) found that dry matter yield and/ or $\mathrm{N}$ uptake of winter cereal crops (wheat and barley) showed significant decreasing trends with periods of cultivation in all soils. They added also that most of the newly reclaimed areas in the deserts are very poor in their organic matter contents as well as their primitive fertility [5]. Enke et al. (2010) indicated that, long-term additions of organic manure have the most beneficial effects on grain yield of wheat and maize [6].

It is customary to consider that all soil in arid and semiarid region having a $\mathrm{pH}$ about 8.5 and this value is strongly affected by continuous cultivation to be adjusted to encourage growing of microorganisms and plant root, period of cultivation and continuous application of organic manure [7]. Part of the solution to poor soil FYM content is continuous addition of FYM, which is concerned with the assessment of land performance when used in maximizing crop production.

Water supply is a major constraint to crop production. Efficient use of irrigation water is becoming increasingly important, and alternative water application methods such as sprinkler irrigation, may contribute substantially toward making the best use of water for agriculture and improving irrigation efficiency especially under cereal crop production $[8,9]$.

Objectives of this study were to investigate the changes of some soil hydrophysical, chemical properties and wheat characters (grain; straw yield, N, P, K, Protein and carbohydrates contents) as affected cultivated period and FYM addition under sprinkler irrigation system.

\section{MATERIAL AND METHODS}

\subsection{Experiments Site and Objectives}

Two field experiments were conducted in two succes- sive season (2011/2012) at two sites El-Emam Malek and El-Shagaah Villages (according to the cultivation periods), Nubaria, Behaira Governorate, the study area located to the west of the Nile Delta between latitudes $30^{\circ}$ $31^{\prime} 44^{\prime \prime} \& 30^{\circ} 36^{\prime} 44^{\prime \prime} \mathrm{N}$ and longitudes $30^{\circ} 20^{\prime} 19^{\prime \prime} \& 30^{\circ} 26^{\prime}$ $50^{\prime \prime E ~(F i g u r e ~ 1) ~ t o ~ s t u d y ~ t h e ~ e f f e c t ~ o f ~ d i f f e r e n t ~ c u l t i v a t e d ~}$ soil period (10 and 25 years) and Farmyard manure as a source of organic matter, OM, (un and continuous application) on wheat characters (grain; straw yield, N, P, K, Protein and carbohydrates contents) under sprinkler irrigation system.

\subsection{Soil, Water, Plant Properties Measurements}

Some soil physical, chemical and water properties of the studied soil are carried out after [10] and moisture retention at field capacity and wilting point after [11]. Soils of both investigated sites were sandy loam in texture. Some soil chemical characteristics of the studied two sites were recorded in Table 1. Analysis farmyard manure used in the experiments was as follow: 4.85 $\mathrm{dSm}^{-1}$ (EC, 1:20), 7.77 (pH, 1:20), 11.2\% (OM), 5.4, 0.85 and $1.12 \%$ total $(\mathrm{N}, \mathrm{P}$ and $\mathrm{K}$ ) and $1: 16.5$ (C:N ratio).

\subsection{Wheat Farming Operations}

The experiment design was randomized complete block in two factors with three replicates. The area of the experimental plot was $12 \times 14 \mathrm{~m}^{2}$ (0.04 feddan). Farmyard manure had been added at the rate of $10 \mathrm{~m}^{3} / \mathrm{fed}$. The organic manure was thoroughly mixed with $0-30 \mathrm{~cm}$ of the surface soil layer before planting. Applied fertilizers were $100 \mathrm{~kg}$ Superphosphate/fed $\left(15.5 \% \mathrm{P}_{2} \mathrm{O}_{5}\right)$ and $50 \mathrm{~kg}$ $\mathrm{K}_{2} \mathrm{O} /$ fed (potassium sulphate $48 \% \mathrm{~K}_{2} \mathrm{O}$ ) were added and well mixed before planting as well as addition recommended dose of nitrogen $(100 \mathrm{~kg} \cdot \mathrm{N} / \mathrm{fed})$ in two equal doses, 4 and 10 weeks after completely germination. Wheat grains (Triticum aestivum L. cv. Gemmaiza 9) were broadcasted on the soil at the rate of $100 \mathrm{~kg} / \mathrm{fed}$. At the maturity stage, the plants were harvested and separated into grains and straw. Production was recorded and prepared for analysis. Soil samples $0-20 \mathrm{~cm}$ ) were taken after wheat harvest for determine some soil hydrophysical and chemical characteristics such as soil bulk density $\left(\mathrm{gm} \cdot \mathrm{cm}^{-3}\right),[10]$. Soil hydraulic conductivity $(\mathrm{HC})$ in saturated condition was measured in the laboratory under a constant head technique [12] using the following formula:

$$
\mathrm{HC}=(\mathrm{QL}) /(\text { At } \Delta \mathrm{H})
$$

where: HC: water quantity flowing through saturated soil sample/unit time, Q: volume of water flowing through saturated soil sample per unite time $\left(\mathrm{L}^{3} / \mathrm{t}\right)$, A: cross sectional flow area $\left(\mathrm{L}^{2}\right) \mathrm{L}$ : length of the soil sample and $\Delta \mathrm{H}$ : 


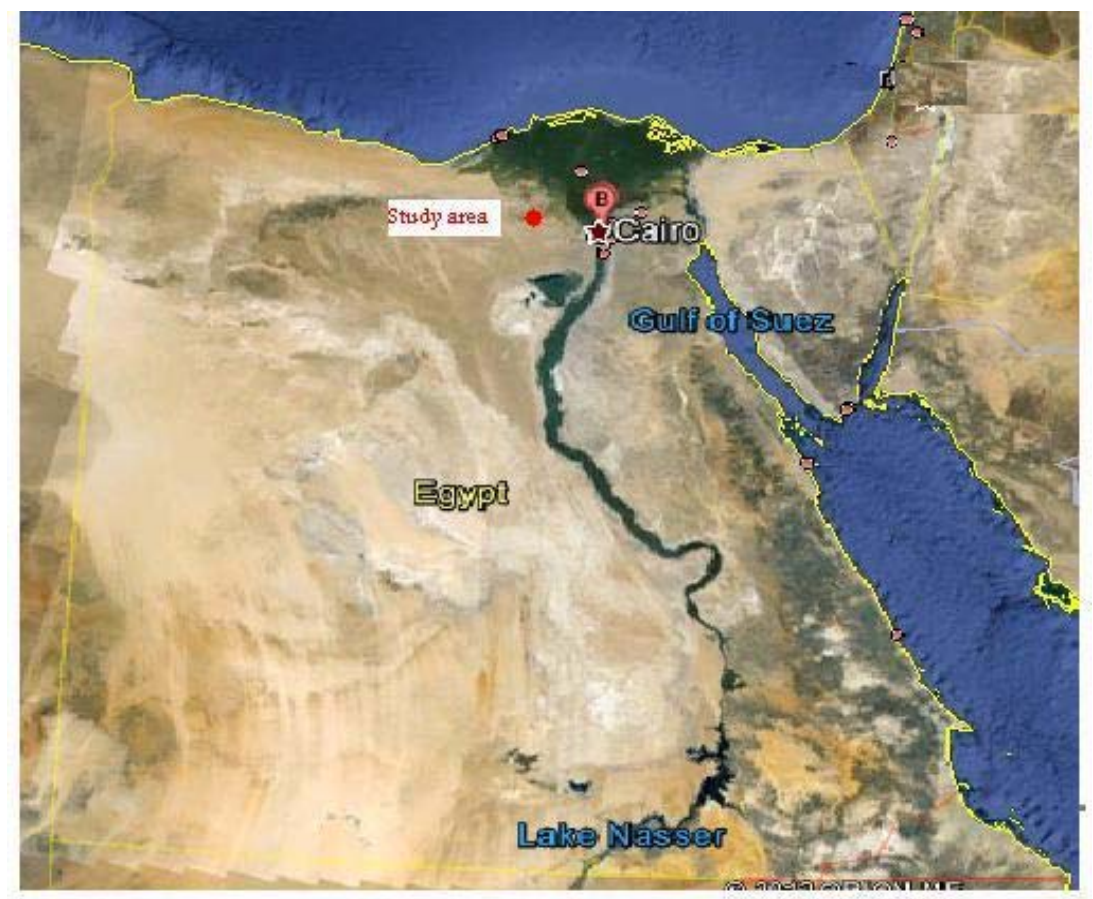

Figure 1. Location of the study area (solid red).

Table 1. Soil properties of the studied sites.

\begin{tabular}{ccccccccc}
\hline \multirow{2}{*}{ Site } & $\mathrm{pH}$ & $\begin{array}{c}\mathrm{EC} \\
\mathrm{dSm}\end{array}$ & & $\mathrm{OM}$ & & $\mathrm{CaCO}_{3}$ & & \multicolumn{2}{c}{ Soil Water Content at (\% vb) } \\
\cline { 5 - 9 } & & & $\%$ & & FC & WP & AW \\
\hline Emam Malek & 8.05 & 2.21 & 0.46 & 5.3 & 9.3 & 3.8 & 5.5 \\
El-Shagaah & 8.23 & 2.56 & 1.12 & 3.6 & 12.8 & 4.7 & 6.2 \\
\hline
\end{tabular}

pH: (1:2.5), EC: electrical conductivity in the extracted soil paste, OM: organic matter, FC: field capacity, WP: wilting point, AW: available water, vb: volume basis.

differences in hydraulic head across the sample (L) and t: time (hr). Soil water retention at 0.1 (field capacity) 15.0 (wilting point) bars and available water were measured after [11]. Total nitrogen, phosphorus and potassium in grain and straw were determined according to the method described by [13]. Carbohydrate contents: Carbohydrate contents of wheat grains were determined in hot water extract by the method of [14]. Dry leaf sample $(0.2$ g) was taken in $10 \mathrm{ml}$ distilled water and kept on boiling water bath for $30 \mathrm{~min}$. For the determination of carbohydrates, $1 \mathrm{ml}$ diluted sample was mixed with $5 \mathrm{ml}$ of Anthron's reagent and then kept on boiling water bath for 30 minutes. The absorbance was measured at $620 \mathrm{~nm}$ after cooling against glucose as standard.

\subsection{Sprinkler Irrigation System and Water Use Efficiency}

Irrigation water was applied using sprinkler irrigation system by fixed lateral lines 1.5 inch in diameter and distance between sprinklers and among lateral lines was
$12 \mathrm{~m}$, supports height was $1.0 \mathrm{~m}$, sub main and main lines were 4 and 6 inches diameter, respectively. Mean of sprinkler discharge was $1.2 \mathrm{~m}^{3} \cdot \mathrm{h}^{-1}$ when mean of operating pressure head was 2 bars. Mean of wind speed 1.5 $\mathrm{m} \cdot \mathrm{sec}^{-1}$. Number of sprinklers on every lateral line were 14 (Figures 2(a)-(f)).

Irrigation water amounts were estimated using the reference evapotranspiration and crop coefficients after [15] while the irrigation timing was determined using a water balance, a common practice among. Calculated amount of water requirements was $\left(550 \mathrm{~mm} \cdot \mathrm{season}^{-1}\right) 2310 \mathrm{~m}^{3}$. $\mathrm{fed}^{-1} \cdot$ season $^{-1}$. Water consumptive use (WCU) was calculated according to [16] by the following equation:

$$
\begin{aligned}
& \text { Wcu }=\sum^{\mathrm{i}=\mathrm{n}}(\theta 2-\theta 1) / 100 \times(\mathrm{DB}) \times(60 / 100) \times(4200) \\
& \mathrm{i}=1 \\
& \text { where Wcu }=\text { Water consumptive use }\left(\mathrm{m}^{3} / \mathrm{fed} .\right) \\
& \mathrm{n}=\text { Number of irrigation } \\
& \theta 2=\text { Soil moisture }(\%) \text { after irrigation } \\
& \theta 1=\text { Soil moisture }(\%) \text { before the next irrigation }
\end{aligned}
$$




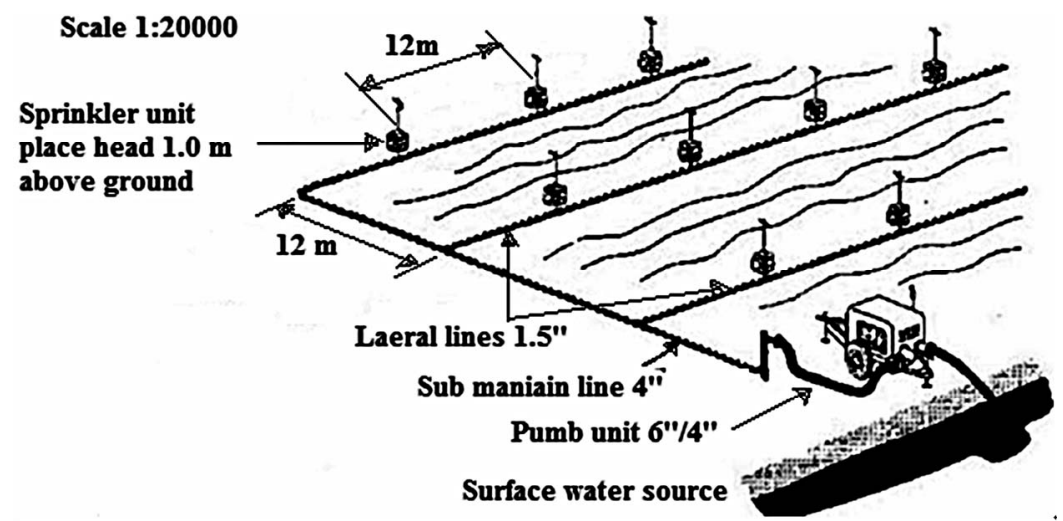

(a)

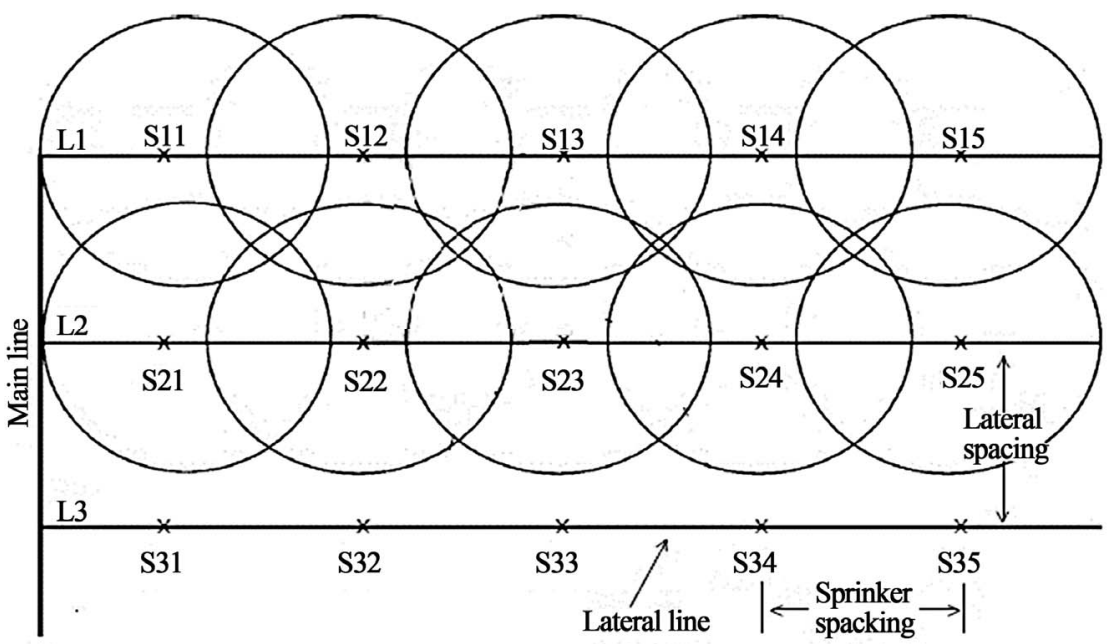

(b)

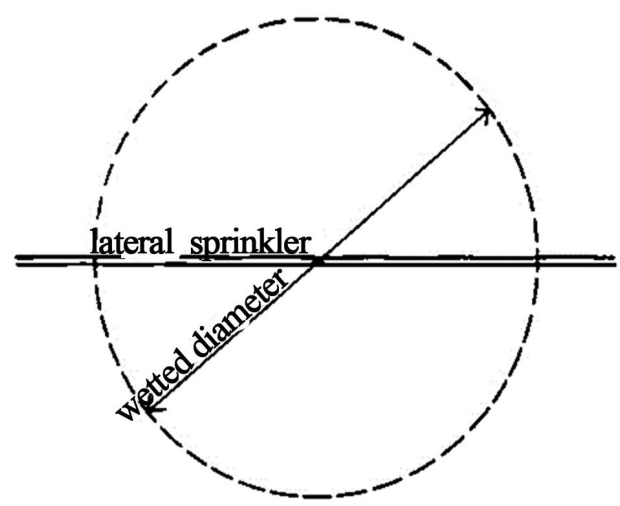

(c)

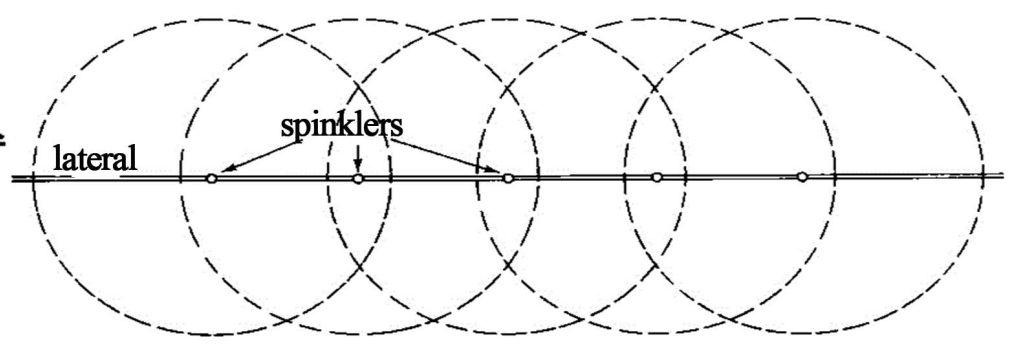

(d)

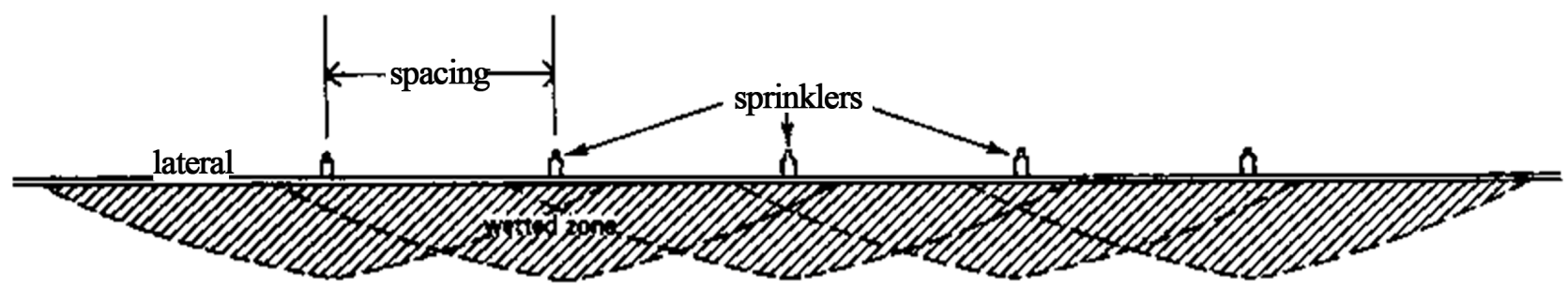

(e)

Figure 2. Layout and explaining operation of fixed sprinkler irrigation system. 
$\mathrm{DB}=$ Bulk density of soil $\left(\mathrm{g} / \mathrm{cm}^{3}\right)$

Field water use efficiency (FWUE): It was calculated as follows [17].

\section{$($ FWUE) $=$ Y/WR}

where:

$\mathrm{Y}=$ Seed yield $\left(\mathrm{kg} \cdot \mathrm{fed}^{-1}\right)$

$\mathrm{WR}=$ The total amount of water applied in the field $\left(\mathrm{m}^{3} \cdot\right.$ fed $\left.^{-1}\right)$.

Crop water use efficiency (CWUE): It was calculated as follows [17].

\section{$($ CWUE $)=$ Y/WCU}

where:

$\mathrm{Y}=$ Seed yield $\left(\mathrm{kg} \cdot \mathrm{fed}^{-1}\right)$ and $\mathrm{WR}=$ Actual water consumptive use $\left(\mathrm{m}^{3} \cdot \mathrm{fed}^{-1}\right)$.

Data were subjected to analysis of variance in randomized complete block design as factorial (two factors) and means were separated according to LSD test, correlation and multiple regressions were estimated after computer's program provided by using the SAS program (2001) [18].

\section{RESULTS AND DISCUSSION}

\subsection{Water Requirements}

The crop water requirement (CWR) table shows that wheat water requirement is increasing with the passage of time and require maximum amount of water at the crop development and mid-season stage (Table 2). Wheat ETc varied from 0.8 (May) to 5.4 (March) $\mathrm{mm} / \mathrm{month}$. The maximum CWR was observed in the month of March (167.4 mm/month) while the minimum was $(24.8$ $\mathrm{mm} / \mathrm{month}$ ) observed in the month of May. Values of CWR increases in the month of March (28.4 mm/month) as wheat was in maturity stage. It was also found that crop water requirement was less in the maturity stage as compared to the initial stage. This finding is close to that obtained by [15].

\subsection{Some Soil Properties}

Data in Table 3 showed the studied soil properties af- ter harvest of wheat plants. Data revealed that addition of FYM decreased soil bulk density (SBD) by about $-1.2 \%$ and $-3.8 \%$ relative to the control treatment under 10 and 25 years cultivated periods, respectively. Also, SBD after 25 years cultivation periods decreased by about $-4.3 \%$ comparing with 10 years one. While SBD decreased by about $-6.8 \%$ comparing 25 years with 10 years cultivation period. Soil BD was lower in the long period cultivated site than short one; however the result corresponds with the observation of [19] and [5] that SBD decreases with increase in the period of cultivation. This otherwise show that as cultivation causes accumulate in the OM, the SBD decreases. While [20] reported that there was no clear effect of short-term cultivation as long one on SBD.

Water movement in soil under saturated condition expressed by hydraulic conductivity (HC) values was strongly affected by cultivation period and FYM addition. One can notice that both the studied factors (cultivated period and FYM addition) significantly decreased HC values by about $18.9 \%$ and $12.1 \%$ in same sequences (Table 3).

According to the soil water content at field capacity (FC), wilting point (WP) and available water (AW) (Table 3), data noticed that cultivation period has more pronounced effect than FYM addition. The percentages of the increases of the previous parameters were $15.1 \%$, $9.3 \% ; 19.0 \%$ and $25.7 \%, 19.5 \%$ and $30.0 \%$ for FYM and cultivation period comparing with control one.

Data also showed that soil HC is strong positive correlated with SBD, Soil $\mathrm{pH}$ Soil EC, while negatively correlated at $1 \%$ were observed with soil water constant $(\mathrm{FC}$, WP and AW), FYM content and soil content of $\mathrm{N}$ and $\mathrm{P}$. Whereas, soil water constant positively correlated with soluble $\mathrm{N}, \mathrm{P}$ and $\mathrm{K}$ in soil. This mainly attributed to its role in modification of SBD and hence water retained in soil at different suction, especially at FC, WP and AW. Also, improvement in soil structure was associated with improvement in water movement in soil under saturated flow (HC). Also, root plant growth is strongly correlated with both cultivation period and FYM addition. This

Table 2. Water requirements for wheat crop at Nubaria sites, Egypt.

\begin{tabular}{|c|c|c|c|c|c|c|}
\hline Month & Dec & Jan & Feb & Mar & Apr & May \\
\hline ETo (mm/day) & 2.8 & 6.25 & 5.87 & 4.15 & 7.4 & 2.0 \\
\hline $\mathrm{Kc}$ & 0.4 & 0.4 & 0.8 & 1.3 & 0.5 & 0.4 \\
\hline ETc (mm/day) & 1.1 & 2.5 & 4.7 & 5.4 & 3.7 & 0.8 \\
\hline Growth stage & $\begin{array}{c}\text { Planting } \\
\text { (establishment) }\end{array}$ & \multicolumn{2}{|c|}{ Rapid vegetative growth } & Flowering-seed fill & \multicolumn{2}{|c|}{ Maturity and harvesting } \\
\hline $\operatorname{IRg}(\mathrm{mm} / \mathrm{month})$ & 36.3 & 85.2 & 149.9 & 184.1 & 122.1 & 27.2 \\
\hline IRn (mm/month) & 33.0 & 77.5 & 136.3 & 167.4 & 111.0 & 24.8 \\
\hline
\end{tabular}

ETo: evapotranspiration, Kc: crop factor, ETc: crop evapotranspiration, IRg: growth water requirements, IRn: net water requirements. 
Table 3. Effect of cultivated period and organic manure on some soil properties at the end of the wheat growing season.

\begin{tabular}{|c|c|c|c|c|c|c|c|c|c|c|c|c|}
\hline \multirow{2}{*}{$\begin{array}{l}\text { Cultivated } \\
\text { period (A) }\end{array}$} & \multirow{2}{*}{$\begin{array}{c}\text { FYM } \\
\text { addition (B) }\end{array}$} & \multirow{2}{*}{$\begin{array}{c}\mathrm{HC} \\
\mathrm{cm} / \mathrm{h}\end{array}$} & \multirow{2}{*}{$\underset{\mathrm{gm} / \mathrm{cm}^{3}}{\mathrm{BD}}$} & $\mathrm{FC}$ & WP & AW & \multirow{2}{*}{$\mathrm{pH}$} & \multirow{2}{*}{$\begin{array}{c}\mathrm{EC} \\
\mathrm{dS} / \mathrm{m}\end{array}$} & \multirow{2}{*}{$\begin{array}{c}\mathrm{OM} \\
\%\end{array}$} & $\mathrm{~K}$ & $\mathrm{P}$ & TS N \\
\hline & & & & & $\%$ wb & & & & & \multicolumn{3}{|c|}{ Ppm } \\
\hline \multirow[t]{3}{*}{10 Years } & - & 11.5 & 1.62 & 9.3 & 3.8 & 5.5 & 8.22 & 2.37 & 0.65 & 36.4 & 7.86 & 52.5 \\
\hline & + & 10.7 & 1.60 & 10.8 & 4.3 & 6.5 & 8.05 & 2.52 & 0.78 & 42.9 & 9.16 & 95.1 \\
\hline & mean & 11.1 & 1.61 & 10.05 & 4.05 & 6.00 & 8.14 & 2.45 & 0.72 & 39.7 & 8.51 & 73.8 \\
\hline \multirow[t]{3}{*}{25 Years } & - & 9.9 & 1.57 & 11.8 & 4.7 & 7.1 & 8.12 & 1.98 & 0.85 & 38.4 & 7.92 & 108.5 \\
\hline & + & 8.1 & 1.51 & 13.5 & 5.1 & 8.4 & 8.01 & 2.06 & 1.21 & 54.1 & 9.78 & 122.5 \\
\hline & mean & 9.0 & 1.54 & 12.7 & 4.9 & 7.8 & 8.07 & 2.02 & 1.03 & 46.3 & 8.85 & 115.5 \\
\hline \multirow[t]{2}{*}{ LSD $5 \%$} & A or B & 1.2 & 0.03 & 1.4 & 0.2 & 0.4 & 0.05 & 0.06 & 0.12 & 2.3 & 0.7 & 6.5 \\
\hline & $A \times B$ & 0.8 & 0.02 & 1.1 & 0.1 & 0.2 & 0.03 & 0.04 & 0.09 & 1.7 & 0.5 & 4.8 \\
\hline
\end{tabular}

agrees with the findings of [21] who found that cultivation practices change soil water content, aeration, and the degree of mixing of crop residues within the soil matrix, thereby affecting soil organisms, which have important functions in soils such as structure improvement, nutrient cycling and organic manure decomposition [22].

Total soluble N, P and $\mathrm{K}$ in soil were measured at the end of the growing season of wheat plants. Results showed that control treatments were lowest content of the studied nutrients under 10 than 25 years cultivated period by about $-5.2,-0.8$ and -51.6 , respectively regarding to the effect of cultivation period on the investigated plant nutrients, obtained results pointed out that there is an increase in soil nutrient resulting to the cultivation period $21.2,4.6 ; 56.5,5$ and to FYM addition $29.7 \%, 20.0 \%$ and $35.2 \%$ in same sequences. This is in line with [23].

\subsection{Macronutrients and Protein and Carbohydrates in Wheat Grain and Straw}

Table 4 illustrated N, P and K content in grain. Data noticed that cultivated period had less effect on the above nutrients content in grain than FYM, where the increase percentage were $5.2 \%, 13.5 \% ; 3.8 \%$ and $26.5 \%, 21.3 \%$; $22.6 \%$ comparing 25 with 10 years and FYM addition with control, respectively. One can notice that effect of FYM individually under two studied cultivated periods is more effective under 10 years $(28.0 \%, 25.2 \% ; 15.1 \%)$ than the 2 nd one $(25.1 \%, 25.2 \% ; 15.1 \%)$ comparing with untreated FYM plots. While N, P and $\mathrm{K}$ content in wheat straw values had unclear trend and the increase percentage of these nutrients were $6.8 \%, 23.23 \% ; 56.5 \%$ and $62.9 \%, 6.0 \% ; 29.8 \%$ as a result of FYM addition under 10 and 25 years cultivated periods.

With respect to the protein and carbohydrates content in wheat grains as affected by cultivated period and OM addition, data recorded in Table 4 indicated that the highest values $(12.86 \%$ and $67.43 \%)$ were obtained under cultivated period 25 years after FYM addition. Also, the lowest ones $(10.29 \%$ and $55.16 \%)$ were attained in cultivated periods 10 years without FYM addition for protein and carbohydrates contents in wheat grains. Individually effect of both investigated factors, cultivated period and FYM addition, there no big difference between increase values relative to their effect $(11.5 \%$ and $12.0 \%)$ for protein content, while there is big difference between their effect on carbohydrates content (15.4\% and 5.9\%), respectively.

Regarding to the effect of both investigated factors, FYM showed strong effect on the above mentioned nutrients content in straw and the increase were $32.6 \%$, $13.8 \%$ and $27.8 \%$ in same sequences. Whereas cultivated period 25 years had a slightly effect on studied nutrients status in wheat straw with change values were $12.0 \%$, $4.6 \%$ and $1.7 \%$ relative to 10 years cultivated period.

According to wheat straw content from protein, obtained data revealed that FYM addition had a promoted effect under 25 than 10 years cultivated periods with values 61.9 and 6.7 comparing with control, respectively, while FYM alone improved protein content in straw by about $31.9 \%$ comparing with untreated one. Low increase in protein in straw was attained relative to the increase cultivated period by about $7.8 \%$.

[24] continuous cultivation for long periods could enhance leaching of nitrate through the profile. It is well established that the presence of organic manure on the surface protects the soil from erosion, improves infiltration and release nutrients. Lack of soil disturbance was found to result in stratification of soil organic manure [25]. Also, [26] significant increase in $\mathrm{N}$ uptake by maize and wheat was observed with continuous application of organic manures. In wheat plant [27] found that farmyard manure application significantly enhanced the yield and 
Table 4. Effect of cultivated period and organic manure on wheat yield, seed index and water use efficiency.

\begin{tabular}{|c|c|c|c|c|c|c|c|c|c|c|}
\hline \multirow{2}{*}{$\begin{array}{l}\text { Cultivated } \\
\text { period (A) }\end{array}$} & \multirow{2}{*}{ FYM addition (B) } & \multicolumn{5}{|c|}{ Grain } & \multicolumn{4}{|c|}{ Straw } \\
\hline & & $\mathrm{N}$ & $\mathrm{P}$ & $\mathrm{K}$ & Protein & Carbohydrates & $\mathrm{N}$ & $\mathrm{P}$ & K & Protein \\
\hline \multirow{4}{*}{10 Years } & - & 1.68 & 0.276 & 1.13 & 10.29 & 55.16 & 0.73 & 0.220 & 3.22 & 4.20 \\
\hline & + & 2.15 & 0.323 & 1.48 & 11.68 & 58.92 & 0.78 & 0.271 & 5.04 & 4.48 \\
\hline & mean & 1.92 & 0.30 & 1.31 & 10.99 & 57.04 & 0.76 & 0.246 & 4.13 & 4.34 \\
\hline & - & 1.79 & 0.302 & 1.26 & 11.63 & 64.19 & 0.62 & 0.267 & 3.76 & 3.57 \\
\hline \multirow[t]{2}{*}{25 Years } & + & 2.24 & 0.378 & 1.45 & 12.86 & 67.43 & 1.01 & 0.283 & 4.88 & 5.78 \\
\hline & mean & 2.02 & 0.34 & 1.36 & 12.25 & 65.81 & 0.82 & 0.275 & 4.32 & 4.68 \\
\hline \multirow[t]{2}{*}{ LSD 5\% } & A or B & 0.78 & 0.08 & 0.14 & 0.95 & 2.34 & 0.11 & 0.021 & 0.23 & 0.95 \\
\hline & $\mathrm{A} \times \mathrm{B}$ & 0.53 & 0.05 & 0.11 & 0.65 & 1.33 & 0.07 & 0.015 & 0.17 & 0.73 \\
\hline
\end{tabular}

FYM: farm yard manure, -: un-continuous, +: continuous.

$\mathrm{N}, \mathrm{P}$ and $\mathrm{K}$ uptake of wheat. [9] found that the organic manure enhanced grain yield and total $\mathrm{N}$ uptake of wheat compared with unfertilized control.

\subsection{Seed Index, Grain; Straw Yield and Water Use Efficiency}

Table 5 demonstrated the overall status seed index (SI) wheat grain and straw yield and water use efficiency (WUE) as affected by cultivated period and organic matter. Results showed that FYM addition increased SI by $25.5 \%$ and $47.6 \%$ under 10 and 25 years cultivated periods, respectively. However, FYM alone increased SI by $36.6 \%$ (relative to untreated one), while cultivated periods was less significant effect on increasing SI (10.4\%) when comparing 25 with 10 years cultivated periods. Regarding to the water consumptive (WCU) used through growing season of wheat crop, data noticed that the lowest and highest values were recorded at 10 years cultivated period untreated FYM. $\left(2146.6 \mathrm{~m}^{3} / \mathrm{fed} / \mathrm{season}\right)$ and FYM treated plot under 25 years $\left(2123.2 \mathrm{~m}^{3} / \mathrm{fed} / \mathrm{season}\right)$. Also, data indicated that the percentage of saving water according to increase cultivated period from 10 to 25 years and FYM addition were $-1.6 \%$ and $1.3 \%$, respectively.

Regarding to the grain and straw yield of wheat crop, results showed that the highest values were recorded at 10 years cultivated periods + treated FYM $(2966.8 \mathrm{~kg} /$ fed $=19.1 \mathrm{ardap} / \mathrm{fed})$ and 25 years cultivated periods treated with FYM $(3835.6 \mathrm{~kg} / \mathrm{fed}=24$ ardap/fed). Regardless FYM effect, cultivated periods increased grain and straw yield of wheat crop by about $57.6 \%$ and $8.3 \%$. Whereas, FYM increased grain and straw yield by about $39.8 \%$ and $58.8 \%$ relative to the control, respectively.

According to WUE of the wheat grain and straw, data showed that cultivated periods had a significant effect on the WUE values of grain where the increase percentage was $59.8 \%$ and less significant on straw $(9.8 \%)$. The opposite was true in case of FYM effect, where WUE for grain and straw of wheat crop improved by about 41.4 and $60.8 \%$ in same sequences. Considering effect of FYM addition individually under two studied factors, one can notice that 10 years cultivated periods is more pronounced than 25 years where the improvement under two factors were $75.3 \%$ (cultivated periods) and $46.5 \%$ (FYM addition). These finding were in harmony with those obtained by $[28,29]$.

Regarding to the relation between soil $\mathrm{pH}, \mathrm{EC}$ and FYM content from side and water constant parameters (FC, WP and AW) from the other one, data notice that there is significant correlation in case of $\mathrm{pH}$ and $\mathrm{EC}$, which it is positively correlated in FYM situation.

Table 6 indicates that Simple correlation coefficients were estimated between WCU and wheat grain and straw yield, N, P, K, protein and carbohydrates content in wheat grains and N, P, K and protein in wheat straw. Also, negative correlations were observed under all previous studied variables.

Highly significant correlation coefficients at $1 \%$ level were attained with grain yield $\left(-0.991^{* *}\right), \mathrm{P}$ content in grain $\left(-0.920^{* *}\right)$, protein and carbohydrates content in grain $\left(-0.993^{* *}\right.$ and $\left.-0.954^{* *}\right)$ and $\mathrm{P}$ content in straw $\left(-0.964^{* *}\right)$, while at significant level $5 \%$ negative correlation were recorded with straw $\left(-0.734^{*}\right)$, grain content from $\mathrm{N}$ and $\mathrm{K}\left(-0.762^{*}\right.$ and $\left.-0.736^{*}\right)$. Also WCU did not significant correlated with $\mathrm{N}, \mathrm{K}$ and protein content in wheat straw was observed.

\section{CONCLUSION}

There is a strong need to use appropriate assessment techniques to determine the long-term effects of cultivation periods and continuous application of FYM on soil properties. They may have greatly increased plant pro- 
Table 5. Effect of cultivated period and organic manure on wheat yield, seed index and water use efficiency.

\begin{tabular}{|c|c|c|c|c|c|c|c|}
\hline \multirow{2}{*}{ Cultivated period (A) } & \multirow{2}{*}{$\begin{array}{c}\text { FYM } \\
\text { addition (B) }\end{array}$} & \multirow{2}{*}{ SI } & \multirow{2}{*}{$\mathrm{WCU} \mathrm{m}^{3} /$ season } & \multicolumn{2}{|c|}{ Yield (kg/fed) } & \multicolumn{2}{|c|}{ FWUE $\left(\mathrm{m}^{3}\right.$ water $/ \mathrm{kg}$ yield $)$} \\
\hline & & & & Grain & Straw & Grain & Straw \\
\hline & - & 37.2 & 2185.7 & 1562.4 & 1854.7 & 0.71 & 0.85 \\
\hline \multirow[t]{3}{*}{10 Years } & + & 46.7 & 2151.5 & 2966.8 & 3198.7 & 1.38 & 1.49 \\
\hline & mean & 42.0 & 2168.6 & 2264.6 & 2526.7 & 1.05 & 1.17 \\
\hline & - & 37.4 & 2146.6 & 3302.8 & 2211.7 & 1.54 & 1.03 \\
\hline \multirow[t]{2}{*}{25 Years } & + & 55.2 & 2123.2 & 3835.6 & 3258.7 & 1.81 & 1.53 \\
\hline & mean & 46.3 & 2134.9 & 3569.2 & 2735.2 & 1.67 & 1.28 \\
\hline \multirow[t]{2}{*}{ LSD $5 \%$} & $A$ or $B$ & 1.3 & 11.8 & 78.2 & 44.6 & 0.25 & 0.09 \\
\hline & $\mathrm{A} \times \mathrm{B}$ & 0.9 & 8.7 & 45.6 & 37.1 & 0.14 & 0.05 \\
\hline
\end{tabular}

FYM: farm yard manure, -: un-continuous, +: continuous, SI: seed index (g/1000 grain), WCU: water consumptive use, $\left(\mathrm{m}^{3} / \mathrm{fed} / \mathrm{season}\right), \mathrm{FWUE}\left(\mathrm{m}^{3} / \mathrm{kg}\right.$ grain yield).

Table 6. Correlations among some soil properties.

\begin{tabular}{|c|c|c|c|c|c|}
\hline & $\mathrm{HC}$ & $\mathrm{BD}$ & $\mathrm{FC}$ & WP & AW \\
\hline $\mathrm{BD}$ & $0.999^{* *}$ & & & & \\
\hline $\mathrm{FC}$ & $-0.991^{* *}$ & $-0.983^{* *}$ & & & \\
\hline WP & $-0.978^{* *}$ & $-0.968^{* *}$ & $0.996^{* *}$ & & \\
\hline AW & $-0.994^{* *}$ & $-0.988^{* *}$ & $0.999^{* *}$ & $0.991^{* *}$ & \\
\hline $\mathrm{pH}$ & $0.790^{* *}$ & $0.765^{* *}$ & $-0.830^{* *}$ & $-0.812^{* *}$ & $-0.837^{* *}$ \\
\hline $\mathrm{EC}$ & $0.718^{* *}$ & $0.736^{* *}$ & $-0.687^{*}$ & $-0.707^{*}$ & $-0.675^{*}$ \\
\hline $\mathrm{OM}$ & $-0.991^{* *}$ & $-0.991^{* *}$ & $0.971^{* *}$ & $0.946^{* *}$ & $0.980^{*}$ \\
\hline $\mathrm{K}$ ppm & -0.331 & -0.301 & 0.436 & 0.516 & 0.398 \\
\hline P ppm & $-0.664^{* *}$ & $-0.652^{*}$ & $0.657^{*}$ & 0.601 & $0.681^{*}$ \\
\hline TS N ppm & $-0.919^{* *}$ & $-0.899^{* *}$ & $0.963^{* *}$ & $0.976^{* *}$ & $0.955^{* *}$ \\
\hline
\end{tabular}

*: significant at $5 \%,{ }^{* *}$ : significant at $1 \%$.

ductivity compared with untreated ones, resulting in improved soil properties. Also, FYM improve root growth and hence create stable aggregate at which reflect in improving in water movement and retained in soil, FYM decreases soil $\mathrm{pH}$ as a result of decomposing process and microorganism's activity which affect directly on improving root growth, while cultivated period 25 years soil buffer capacity took.

\section{REFERENCES}

[1] Lal, R. (2007) Anthropogenic influences on world soils and implications to global food security. Advances in Agronomy, 93, 69-93. doi:10.1016/S0065-2113(06)93002-8

[2] Yassen, A.A., Khaled, S.M. and Sahar, M.Z. (2010) Response of wheat to different rates and ratios of organic residues on yield and chemical composition under two types of soil. Journal of American Science, 6, 858-864.

[3] Franzluebbers, A.J. and Stuedemann, J.A. (2008) Early response of soil organic fractions to tillage and integrated crop-livestock production. Soil Science Society of America Journal, 72, 613-625. doi:10.2136/sssaj2007.0121

[4] Fliessbach, A., Roland, H., Daneil, R., Robert, F. and Frank, E. (2000) Soil organic matter quality and soil aggregates stability in organic and conventional soil. http://orgrints.org/00002911/

[5] Dalal, R.C. and Mayer, R.S. (1986) Long-term trends in fertility of soils under continuous cultivation and cereal cropping in South Western Queensland, I overall changes in soil properties and trends in winter cereal yields. Australian Journal of Soil Research, 24, 265-279. doi:10.1071/SR9860265

[6] Li, E.K., Yan, C.R., Mei, X.R., He, W.Q., Bing, S.H., Ding, L.P., Liu, Q., Liu, S. and Fane, T.L. (2010) Long 
term effect of chemical fertilizer, straw, and manure on soil chemical and biological properties in northwest China. Geoderma, 158, 173-180. doi:10.1016/i.geoderma.2010.04.029

[7] Franzleubbers, A.J. (2002) Soil Organic manure stratification ratio as an indicator of soil quality. Soil \& Tillage Research, 66, 95-106. doi:10.1016/S0167-1987(02)00018-1

[8] Phocaides, A. (2000) Technical hand book on pressurized irrigation techniques, food and agriculture organization of the United Nations. Rome.

[9] Abd El-Kader, A.A., Shaaban, S.M. and Abd El-Fattah, M.S. (2010) Effect of irrigation levels and organic compost on okra plants (Abelmoschus esculentus L.) grown in sandy calcareous soil. Agriculture and Biology Journal of North America, 1, 225-231. doi:10.5251/abjna.2010.1.3.225.231

[10] Rebecca, B. (2004) Soil survey laboratory methods manual. Soil Syrvey Investigations Report No. 42, Natural Resources Conservation Services.

[11] Klute, A. (1986) Water retention: Laboratory methods. In: Klute, A., Ed., Methods of Soil Analysis, Part 1, Physical and Mineralogical Methods, ASA and SSSA, Madison, 635-662.

[12] Klute, A. and Dirksen, A. (1986) Hydraulic conductivity. In: Klute, A., Ed., Methods of Soil Analysis, Part 1, Physical and Mineralogical Methods, ASA and SSSA, Madison, 678-734.

[13] Faithfull, N.T. (2002) Methods in agricultural chemical analysis. A practical handbook. CABI Publishing, Wallingford, 84-95. doi:10.1079/9780851996080.0000

[14] Yemm, E.W. and Willis, A.J. (1954) The estimation of carbohydrates in plant extracts by anthrone. Biochemistry, 57, 508-514.

[15] Allen R.G., Pereira, L.S., Raes, D. and Smith, M. (1998) Crop evapotranspiration-Guidelines for computing crop water requirements-FAO irrigation and drainage paper 56. FAO-Food and Agriculture Organization of the United Nations, Rome.

[16] Israelsen, O.W. and Hansen, V.E. (1962) Flow of water into and through soils. Irrigation principles and practices. 3rd Edition, John Willey and Sons, Inc., New York.

[17] Michael, A.M. (1978) Irrigation theory and practice. Vikas Publishing House, New Delhi.

[18] SAS Institute (2001) SAS statistics users' guide. Release 8.2. SAS Institute, Cary.
[19] Dalal, R.C. (1982) Organic matter content in relation to the period of cultivation and crop yields in some subtropical soils. 12th International Soil Science Congress, 6, 59.

[20] Saeed, A.B. and Eissa, H.Y. (2002) Influence of tillage on some properties of heavy cracking clay soils and sorghum yield in the mechanized rain-fed agriculture. The Journal of Agricultural Science, 10, 267-276.

[21] Schumacher, T.E., Lindstrom, M.J.L., Eynard, A. and Malo, D.D. (2000) Tillage system effects on soil structure in the Upper Missouri river basin. Proceedings of the 15th Conference of ISTRO, Fort Worth, Dallas, 2-7 July 2000

[22] Kladivko, E.J. (2001) Tillage systems and soil ecology. Soil \& Tillage Research, 61, 61-76. doi:10.1016/S0167-1987(01)00179-9

[23] Mubarak, A.R. and Rosenani, A.B. (2003) Soil organic manure fractions in the humid tropics as influenced by application of crop residues. Communications in Soil Science and Plant Analysis, 34, 933-943. doi:10.1081/CSS-120019100

[24] Randall, G.W. and Iragavarapa, T.K. (1995) Impact of long-term tillage systems for continuous corn on nitrate leaching to tile drainage. Journal of Environmental Quality, 24, 360-366. doi:10.2134/jeq1995.00472425002400020020x

[25] Kay, B.D. and Vanden Bygaart, A.J. (2002) Conservation tillage and depth stratification of porosity and soil organic matter. Soil \& Tillage Research, 66, 107-118. doi:10.1016/S0167-1987(02)00019-3

[26] Tawfik, M.M. and Gomaa, A.M. (2005) Effect of organic and biofertilizer on growth and yield of wheat plants. Journal of Agricultural and Resource Economics, 2, 711725 .

[27] Hellal, F.A., Abd El-Hady, M. and Ragab, A.A.M. (2009) Influence of organic amendments on nutrient availability and uptake by faba bean plants fertilizered by rock phosphate and feldspar. American-Eurasian Journal of Agricultural \& Environmental Sciences, 6, 271-279.

[28] EL-Gindy, A.M. and Abdel-Aziz, A.A. (2003) Maximizing water use efficiency of maize crop in sandy soils. Annals of Agricultural Sciences, 11, 439-452.

[29] Abbas, G., Hussain, A., Ahmad, A. and Wajid, S.A. (2005) Water use efficiency of maize as affected by irrigation schedules and nitrogen rates. Journal of Agriculture and Social Sciences, 1, 339-342. 